\title{
A MESSAGE FROM THE CHAIRMAN ON WORKING PARTIES
}

What is the Ecclesiastical Law Society's opinion on the issue? Is that a question which the General Synod and the bishops ask? And if they ask it, will they get an answer?

It was the hope of the Society's founders that answers would be given; learned answers, supported by reason and authority and persuasive withal. That is why part of the Object of the Society is:

'the provision of assistance in matters of ecclesiastical law to the General Synod of the Church of England, the Convocations of Canterbury and York and the bishops and dignitaries of the Church of England'.

We can only provide that assistance and give useful answers to questions the Church is asking its lawyers it we have Working Parties which will produce discussion papers which the Society, either at its conferences or through its General Committee, can consider. After considering the papers and approving or revising them the Society may be able to place them before the Church as a whole.

At present we have four Working Parties; their topics are Establishment, Peculiars, Education in Canon Law and Civil Preliminaries to Marriage. The first report on Peculiars is published in this issue, as is a preliminary report on Civil Preliminaries to Marriage. The Working Party on Education in Canon Law will give an account of its progress towards a more systematic education in canon law in theological colleges at our conference in Oxford this Spring.

There are, however, several topics on which the Society should be preparing to express an opinion. One is the law relating to the appointment and tenure of lay office-holders in the parish. As many will know, the Policy Committee of the General Synod, in June 1994, asked Dr Christina Baxter to be chairman of a working party to produce a report on this subject. She asked bishops, archdeacons and diocesan officers to let her have their views by 10 October, 1994. Miss Ingrid Slaughter, the Secretary of the working party, asked the Society for a response and the General Committee did its best to express some views within the very limited time and opportunities to canvass opinion available. The Committee's memorandum is to be found on page 354 of this issue. Had more notice been given we should, I believe, have been able to find members willing to form a Working Party of the Society to assist Dr Baxter and the General Synod. But it is not too late - General Synod will need to consider and debate Dr Baxter's report when it is published and I hope that a Working Party of the Society may yet be convened to consider this topic further.

Another matter under current discussion within the Church is the consultation paper entitled 'Clergy Conditions of Service', published in August, 1994, by the Clergy Conditions of Service Steering Group. The paper was produced following debates in the Convocations and General Synod on the ecclesiastical freehold and its expressed aim is to sound out opinion in the Church on the future of the freehold and on other aspects of conditions of service of the stipendiary clergy. Views from dioceses are asked for by 2 June 1995 and all responses are to be collated and reported to the newly elected Synod in November 1995. I am sure that an expression of opinion, or opinions, by the Society would be valued by the Group and I hope that another working party of the Society may be convened for that purpose. 
There are other topics, not much less urgent, which call for serious reflection by the Church's lawyers. One is the future administration, staffing and management of cathedrals. 'Heritage and Renewal', the report of the Archbishops' Commission on Cathedrals, published in October, 1994, contains many recommendations, some of which will, if adopted, require changes in the law relating to cathedrals and their chapters.

I am reliably informed that the new Synod will probably be asked to consider the reform of the law relating to clergy discipline and the church courts. This is plainly a field in which the Society should be asked to provide assistance to the General Synod.

Another more general, but ever continuing, subject is how the Church may come to terms with the requirements of the secular law. In matters of planning, rating, employment and insurance, difficult questions frequently arise and it would be most useful to have a standing Working Party ready to offer solutions to problems as and when they occur.

I urge every member to ask himself (and the masculine most certainly includes the feminine) whether he can help the Society and the Church by forming or joining a Working Party, either on one of the above topics, or on some other subject - and there are many, for the brief list mentioned above is by no means exhaustive. If any member would be interested in doing so and will write to me or speak to me on the telephone I shall do my best to arrange for those interested in the same topic to be informed about each other. I can also advise on procedure and publication and should be able to give publicity, in the Journal and at the Society's conferences, about any Working Party formed.

The Lord be with you.

Quentin Edwards

Chairman

13 South Grove

Highgate

London N6 6BJ

01813404861

\section{RECENT LEGISLATIVE DEVELOPMENTS: ENGLAND}

Due to the timing of the November meeting of the General Synod, Brian Hanson's report on its legislative proceedings is necessarily deferred to the next issue of the Journal. 